\title{
A CRITICAL INTRODUCTION TO THE
}

POEMS OF THOMAS HARDY 
Trevor Johnson has also written:

Thomas Hardy (1968)

Thomas Hardy: An Annotated Reading List (1974)

Joseph Andrews by Henry Fielding (A Critical Guide) (1987)

He is the editor of Poems by Thomas Hardy (an anthology) (1979)

and the co-editor, with James Gibson, of Thomas Hardy, Poems:

a Casebook (of critical comment on Hardy's verse) (1979). 


\section{A CRITICAL \\ INTRODUCTION TO \\ THE POEMS OF \\ THOMAS HARDY}

Trevor Johnson

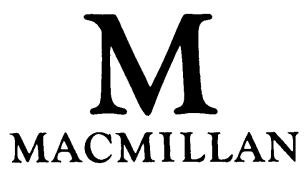




\section{(C) HENRY ANTHONY TREVOR JOHNSON 1991}

All rights reserved. No reproduction, copy or transmission of this publication may be made without written permission.

No paragraph of this publication may be reproduced, copied or transmitted save with written permission or in accordance with the provisions of the Copyright, Designs and Patents Act 1988 or under the terms of any licence permitting limited

copying issued by the Copyright Licensing Agency, 33-4 Alfred Place, London WC1E 7DP.

Any person who does any unauthorised act in relation to this publication may be liable to criminal prosecution and civil claims for damages.

First published 1991

Published by

MACMILLAN EDUCATION LTD

Houndmills, Basingstoke, Hampshire RG21 2XS

and London

Companies and representatives

throughout the world

British Library Cataloguing in Publication Data

Johnson, Trevor, 1929-

A critical introduction to the poems of Thomas Hardy.

1. Poetry in English. Hardy, Thomas, 1840-1928

I. Title

821.8

ISBN 978-0-333-49578-0

ISBN 978-1-349-21221-7 (eBook)

DOI 10.1007/978-1-349-21221-7 


\section{Contents}

1 Introduction 1

2 Hardy's Life $\quad 6$

3 Hardy's Poetry: a general survey 36

4 Poems about People 55

Autobiographical poems $\quad 55$ Analyses 63

Biographical poems $\quad 75$ Analyses $\quad 78$

Narrative poems $\quad 82$ Analyses $\quad 88$

5 Poems about Seasons, Places and Things 98

Poems about seasons and places $\quad 98$ Analyses $\quad 110$

Poems about things, animals, birds, plants, etc. $\quad 115$ Analyses 123

6 Poems about Ideas 129

Satirical poems 131 Analyses $\quad 134$

War poems 138

Analyses $\quad 141$

Poems about God and Nature $\quad 145$

Analyses 148

Reveries $\quad 149$

Analyses 156

7 Love Poems I 170

$\begin{array}{ll}\text { Early love poems } & 172\end{array}$ 
Analyses $\quad 178$

Mature love poems $\quad 179$

Analyses 193

8 Love Poems II: Poems about Emma 199

Lyonnesse poems $\quad 200$

Analyses $\quad 207$

Poems of 1912-13, including Analyses 216

Poems of marriage, including Analyses 237

Further Reading 244

$\begin{array}{ll}\text { Index } & 250\end{array}$ 
For my wife, Margaret, without whom I should never finish anything, and my daughters, Sarah and Kate. 


\section{Acknowledgements}

The author and publishers are indebted to The Folio Society for their permission to use the wood-engraved portrait of Thomas Hardy by Jacques Hnizdovsky which adorns the front cover and to the Librarian and Fellows of Magdalene College, Cambridge for their permission to reproduce Hardy's manuscript of During Wind and Rain, which forms the frontispiece.

The text used for Hardy's poems is that of Dr James Gibson's Thomas Hardy: The Complete Poems (Macmillan, 1976) and I also owe a great deal to his Variorum Complete Poems. To the late J. O. Bailey's and to Frank Pinion's handbooks to Hardy's verse I am often indebted, while no one who writes on Hardy can afford to neglect Michael Millgate's definitive biography.

It would be invidious to single out individuals among the many critics from whose work I have profited over the years, but I take this occasion to thank the many generations of English students at Mather and at the City of Manchester Colleges, from whose insights into Hardy's poems this book will derive a good deal of any value it may have.

Finally, to those who may have read my previous articles and essays on Hardy's poetry, and who recognise occasional fragments from them embedded in this book, I hope they will forgive me if, where I felt I could not improve on what I had already said of a poem, I have let it stand here.

TREVOR JOHNSON

Note on abbreviations

Throughout the text I have employed the following abbreviations:

(1) Life (or The Life) for The Life of Thomas Hardy by F. E. Hardy (Macmillan, 1962).

(2) MS for [Hardy's] holograph manuscript, i.e. of the poems in question.

Other abbreviations are dealt with in the sections where they occur. 
During Wins ot Rain

Then sing their dearest sore He, she, all item - yea.

Treble oberon + bass.

and one wiley:

Win the can oles mooring each face,... ah, ho: the yeans 0 !

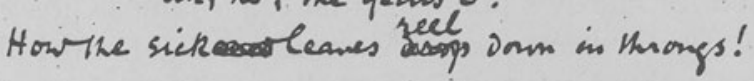

They clear the crapping moss -

Elias juniors - yea,

shaving the pathwaing neat

and the javier gay:

and they frit \& shay seat:...

ah, no; the years 0 !

see, The weber white storm. lis ios wing accost

Then are blithely breakfasting all then triaisen-yea,

quiver the summa tree,

With a glimpse $q$ hie bay.

while pot blinis come wo te knee....

ah, no: the yeans O!



They 


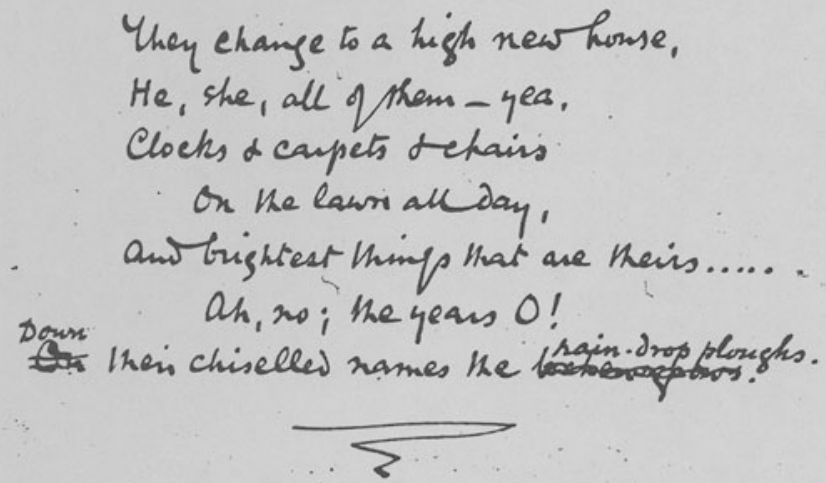

During Wind and Rain (441/ALL/*). The MS shows Hardy's clear, strong handwriting. Hardy's emendations to the text given here are discussed in the detailed analysis of the poem on pp. 167-9. Reproduced by permission of the Master and Fellows, Magdalene College, Cambridge. 